\section{Authors' reply}

\section{Eyas Alkhalili, Alissa Greenbaum, Li Luo, Rodrigo Rodriguez, Katharine Caldwell, Oscar Munoz Estrada, Jacqueline O'Neill, Itzhak Nir, Katherine T. Morris}

University of New Mexico, New Mexico, USA

We would like to thank Dr Spartalis et al for their interest in our article [1]. It has been shown that human immunodeficiency virus and hepatitis $\mathrm{C}$ virus (HIV-HCV) coinfection is associated with shorter survival in patients with hepatocellular carcinoma (HCC) [2]. In addition, the presence of hepatitis $\mathrm{B}$ or $\mathrm{C}$ is associated with an increased risk of HCC in HIV patients [3]. We thus agree that HIV$\mathrm{HCV}$ coinfection is associated with a worse prognosis in patients with HCC. However, since our cohort did not include any patients with HIV infection we were not able to study this group.

\section{References}

1. Alkhalili E, Greenbaum A, Luo L, et al. Viral hepatitis status does not affect survival in patients with hepatocellular carcinoma. Ann Gastroenterol 2017;30:101-105.

2. Lewin M, Gelu-Simeon M, Ostos M, et al. Imaging features and prognosis of hepatocellular carcinoma in patients with cirrhosis who are coinfected with human immunodeficiency virus and hepatitis C virus. Radiology 2015;277:443-453.

3. Ioannou GN, Bryson CL, Weiss NS, Miller R, Scott JD, Boyko EJ. The prevalence of cirrhosis and hepatocellular carcinoma in patients with human immunodeficiency virus infection. Hepatology 2013;57:249-257.

Department of Surgery, School of Medicine, University of New Mexico, New Mexico, USA

Conflict of Interest: None

Correspondence to: Eyas Alkhalili, MD, Office 1, UNM HSC

Department of Surgery, MSC 10 5610, 1 UNM, Albuquerque, New

Mexico 87131, USA, e-mail: EAlkhalili@salud.unm.edu

Received 30 March 2017; accepted 30 March 2017;

published online 25 April 2017

DOI: https://doi.org/10.20524/aog.2017.0150 